\title{
A Clinical case study on Dhanyak Gokshur Ghrita Yavakshar Uttar basti in the Management of Mutraghata w.s.r. to Benign Prostatic Hyperplasia
}

\author{
Case Report
}

\section{Shailesh Jaiswal1*, Hemant Toshikhane ${ }^{2}$, Mukund Dhule ${ }^{3}$, Parappagoudra $\mathbf{M}^{4}$}

1. Ph.D. Scholar and Associate Professor, 2. Principal, 3. HOD, Department of Shalya Tantra, 4. Ph.D. Scholar and Assistant Professor, Department of Panchakarma Parul Institute of Ayurved, Parul University, Vadodara.

\begin{abstract}
Benign Prostatic Hyperplasia is a common senile disease. The present modern conservative management includes use of alpha blockers and 5 alpha reductase inhibitors. In operative management various type of operative procedure may be done, out of which most commonly done now-a-days is TURP. However, both of these modalities cause various side effects. Through Ayurveda we can find solution for this burning problem of society. In Ayurved Samhitas, symptoms of Benign Prostate Hyperplasia described under Mutraghata disease. There are 12 types of Mutraghata; one of them is Vatashthila, which can be correlated with Benign Prostatic Hyperplasia disease. The general treatment of Mutraghata includes Uttar basti. Though Uttar basti is a traditionally used therapy, its efficacy with Dhanyak Gokshur Ghrita Yavakshar is not yet evaluated in the management of BPH. Uttar basti is cost effective and it may avoid surgery which ultimately results in increased quality of life of patients. So, in present clinical study, efficacy of Dhanyak Gokshur Ghrita Yavakshar Uttar basti in Vatashthila with special reference to Benign Prostatic Hyperplasia is evaluated.
\end{abstract}

Key Words: Mutraghata, Vatashthila, Dhanyak Gokshur Ghrita Yavakshar, Benign Prostate Hyperplasia.

\section{Introduction}

Benign Prostate Hyperplasia is an enlargement of prostate. Symptoms related to BPH are one of the most common problems in the older males. As the prostate enlarges, it causes the narrowing of urethra \& subsequent partial emptying of bladder, results in many of the problems associated with $\mathrm{BPH}$. In modern medicine the conservative treatment is very costly and has side effects. Prostatectomy is the primary approach to Benign Prostate Hyperplasia(1). Even if the surgery is performed, there may be a risk of complications. Considering complications, recurrence \& cost of surgery, it is the need of society to evaluate an alternative option for this most predominant senile disease. There are 12 types of Mutraghata; one of them is Vatashthila. In Sushrut Samhita, Vatashthila is grouped under the title of Mutraghata, the general treatment for Mutraghata includes Uttar basti(2). For the above reason and treatment indication this topic is taken for case study.

\section{Aims and Objectives}

To study the effect of Dhanyak Gokshur Ghrita Yavakshar Uttarbasti in Mutraghata w.s.r. to Benign Prostatic Hyperplasia.

\section{* Corresponding Author:}

\section{Shailesh Jaiswal}

Ph.D scholar and Assistant Professor,

Department of Shalya Tantra,

Parul Institute of Ayurveda,

Parul University, Vadodara, Gujarat. India.

Email Id: shailesh.skp61@gmail.com
Place of work

Clinical study done at Parul Ayurveda Hospital.

\section{Case Report}

A 60 year old male came at OPD of Shalya

Tantra at PAH, presenting complaint since one month:

$\mathbf{C} \backslash \mathbf{o}-$

- Incomplete void

- Frequency

- Intermittency, Urgency

- Weak Stream

- Straining

- Nocturia

\section{On examination}

- General condition was moderate and afebrile. Pulse $-72 / \min$

- Blood pressure $-140 / 80 \mathrm{~mm} / \mathrm{Hg}$

- No pallor, no icterus

- Systemic examination - RS - AEBE

- CVS - S1, S2 heard

- CNS - Conscious oriented. P/A - Lower Abdominal tenderness present, Liver, Spleen not palpable.
Ashtavidh Pariksha
- Nadi -72/min.
- Druka-Samyak
- Mala-Samyaka
- Sparsha-Anushna
- Mutra-Asamyak
- Akruti-Madhyam
- Jivha-Niram
- Shabda-Samyak 
Shailesh Jaiswal et.al., Study on Dhanyak Gokshur Ghrita Yavakshar Uttar basti in the management of Mutraghata

\section{Present Illness}

Before 1 month patient was apparently normal, later on patient got these following symptoms, Incomplete Emptying, increased frequency of urination, Intermittency, Urgency of urination and Weak Stream. He took treatment from nearby modern hospital but didn't get any relief, so he came for its management in OPD of Shalya Tantra of Parul Ayurved Hospital Vadodara.

\section{Past history}

Patient is known case of Hypertension and Type 2 Diabetes Mellitus since 5 years and he was on treatment for same.

Local examination - External Urethral Meatus - normal.

PR Digital - Prostatomegaly, Non tender, smooth, firm, elastic enlargement.

\section{Investigation}

- HB - $13.2 \mathrm{gm} \%$,

- BSL(R)- $74 \mathrm{mg} / \mathrm{dl}$,

- HIV 1 \& 2 - Non reactive,

- HBsAg - Non reactive.

- Serum creatine - $1.03 \mathrm{mg} / \mathrm{dl}$.

- Blood urea - $21 \mathrm{mg} / \mathrm{dl}$.

\section{Diagnosis}

The condition was diagnosed as a Benign Prostatic Hyperplasia. (Mutraghata).

\section{Materials and Methods}

- Dose : 30ml Dhanyak Gokshur Ghrit + 125 mg (1ratti) Yavakshar.
- Regime : Uttar basti daily for 7 days.

- Duration of study: 7 days.

- Follow up : after 1 month.

- Procedure of Uttar basti:-

\section{Purvakarma}

Informed \& written consent was taken before Uttar basti. Patient was advised to sleep in supine position.

Painting \& draping of part done. Dhanyak gokshur Ghrita with Yavakshar and all instruments including $50 \mathrm{ml}$ syringe, 10 no feeding tube and all materials were steam autoclaved in autoclave machine under all aseptic precautions.

\section{Pradhankarma}

In aseptic precautions, $50 \mathrm{ml}$ glass syringe filled with Dhanyak gokshur Ghrita $30 \mathrm{ml}$ and with Yavakshar $125 \mathrm{mg}$ was taken into right hand.

Xylocaine jelly $2 \%$ was instilled in penis. Lukewarm Dhanyak gokshur Ghrita mixed with Yavakshar $30 \mathrm{ml}$ was inserted slowly through by syringe in feeding tube inserted in mutramarg. After that, penis was held firmly atleast for 5 minutes to avoid reverse flow of Dhanyak gokshur Ghrita with Yavakshar.

\section{Paschatkarma}

Patient was kept in same supine position for 15 minutes.

Patient was instructed not to void urine for next 1 hour.

\section{Criteria for Assessment of Therapy}

Subjective Criteria

Table 1 - International Prostate Symptom Score (I-PSS)(4)

\begin{tabular}{|l|c|c|c|c|c|c|}
\hline In the past Month & $\begin{array}{c}\text { Not at } \\
\text { all }\end{array}$ & $\begin{array}{c}\text { Less } \\
\text { than1 in } \\
\text { 5 times }\end{array}$ & $\begin{array}{c}\text { Less than } \\
\text { half the } \\
\text { times }\end{array}$ & $\begin{array}{c}\text { About } \\
\text { half the } \\
\text { time }\end{array}$ & $\begin{array}{c}\text { More } \\
\text { than half } \\
\text { the time }\end{array}$ & $\begin{array}{c}\text { Almost } \\
\text { always }\end{array}$ \\
\hline $\begin{array}{l}\text { Incomplete emptying: How often have you had the } \\
\text { sensation of not emptying your bladder? }\end{array}$ & 0 & 1 & 2 & 3 & 4 \\
\hline $\begin{array}{l}\text { Frequency : } \\
\text { How often have you had to urinate less than every two } \\
\text { hours? }\end{array}$ & 0 & 1 & 2 & 3 & 4 \\
\hline
\end{tabular}

\begin{tabular}{|c|c|c|c|c|c|c|}
\hline $\begin{array}{l}\text { Intermittency: How often have you found you stopped and } \\
\text { started again several times when you urinated? }\end{array}$ & 0 & 1 & 2 & 3 & 4 & 5 \\
\hline $\begin{array}{l}\text { Urgency: } \\
\text { How often have you found it difficult to postpone } \\
\text { urination? }\end{array}$ & 0 & 1 & 2 & 3 & 4 & 5 \\
\hline $\begin{array}{l}\text { Weak stream: } \\
\text { How often have you had a weak urinary stream? }\end{array}$ & 0 & 1 & 2 & 3 & 4 & 5 \\
\hline $\begin{array}{l}\text { Straining: } \\
\text { How often have you had } \\
\text { to strain to start urination? }\end{array}$ & 0 & 1 & 2 & 3 & 4 & 5 \\
\hline
\end{tabular}

\section{Objective Criteria}

USG with pelvis before treatment and after treatment was observed for

1. Weight of prostate.

2. Post voidal residual volume. 


\section{Results}

Table 2: International Prostate Symptom Score (I-PSS)

\begin{tabular}{|c|c|c|c|c|c|}
\hline \multirow{2}{*}{\multicolumn{2}{|c|}{ Symptoms }} & \multicolumn{4}{|c|}{ Score } \\
\hline & & $1^{\text {st }}$ day & $7^{\text {th }}$ day & $15^{\text {th }}$ day & 30th day \\
\hline & Incomplete Emptying & 5 & 5 & 2 & 1 \\
\hline 2 & Frequency & 5 & 2 & 1 & 1 \\
\hline 3 & Intermittency & 5 & 4 & 2 & 0 \\
\hline 4 & Urgency & 5 & 3 & 3 & 0 \\
\hline 5 & Weak Stream & 5 & 4 & 0 & 0 \\
\hline 6 & Straining & 5 & 2 & 0 & 0 \\
\hline 7 & Nocturia & 5 & 2 & 2 & 1 \\
\hline & Total IPSS Score & 35 & 22 & 11 & 3 \\
\hline
\end{tabular}

Table 3: Objective criteria

\begin{tabular}{|c|c|c|c|}
\hline Sr. No. & USG Findings & $\begin{array}{c}0^{\text {th }} \text { day } \\
\text { (Before } \\
\text { Treatment) }\end{array}$ & $\begin{array}{c}\mathbf{3 0}^{\text {th }} \text { day } \\
\text { (After } \\
\text { Treatment) }\end{array}$ \\
\hline 1 & $\begin{array}{c}\text { Weight of } \\
\text { Prostate }\end{array}$ & $54 \mathrm{gm}$ & $46 \mathrm{gm}$ \\
\hline 2 & Post void urine & $150 \mathrm{ml}$ & Nil \\
\hline
\end{tabular}

\section{Discussion}

Yavakshar reduces the weight of prostate due to its Ushna, Tikshna Guna and causing Lekhana karma of Mamsa Vaha Srotas, so that the pressure over the prostate urethra is reduce, which helps for emptying of bladder. As a result of that post voidal residual urine volume decreases significantly and therefore it reduces the intermittency, frequency, urgency, weak stream, straining and Nocturia .Dhnayak Gokshur Ghrita Uttar basti also reduces the weight of prostate due to act on the muscles of bladder and the sphincter, giving strength to them, so that patient can hold the urine and the urgency is markedly reduced. Dhanyak and Gokshur both have Linoleic Acid and Oleic Acid as a chemical component. They are inhibitors of both 5 Alpha reductase and Alpha blockers activity. This inhibition controls the conversion of testosterone to Dihydrotestosterone (DHT). DHT ultimately controls the further growth of prostate gland and relief in the symptoms. Dhanyaka Gokshur Ghrita (DGG) with Yavakshara for Uttra Basti. Ayurvedic pharmacodynamic properties of formulations are mentioned below based on collective pharmacodynamic properties of their ingredients.

\section{Pharmacodynamic Properties of Dhanyaka Gokshur}

Ghrita

- Rasa

$$
\text { : Kashaya, Madhura }
$$

- Guna

: Snigdha, Sheeta

- Veerya

- Vipaka

: Anooshna Sheeta

- Karma : Katu

- Doshaghnata : Vata-Kapha Hara

- Rogaghnata : Mutraghata, Prameha, Mootrakrichha, Ashmaree, Shukradosha

Its effect on Mutraghata i.e. BPH had discussed under the mode of drug action in oral use. Dhanyaka
Gokshur Ghrita is a Snehapaka Kalpana and was used in the form of Uttar basti to achieve additional effect via Urethral route with its direct effect to the Granthi. Basti Dravyas may be absorbed by one or more mechanisms of diffusion, filtration and osmosis depending upon nature of ingredients. This theory is the same as the theory propounded by Sushruta ${ }^{14}$, where he has defined that how Basti produces systematic effect in entire body. Sushruta says that the Veerya of Basti reaches to the whole body through the Srotasa (channels) as the active principles in the water when poured in the root of a tree reaches to the whole plant.

\section{Conclusion}

From above case study it can be concluded that the Dhanyak Gokshur Ghrita with Yavakshar Uttar basti is effective in reducing International prostate symptom score, weight of prostate and post residual volume in Mutraghata (Benign Prostate Hyperplasia). In Ayurveda it is mentioned that Uttar basti is choice of treatment in controlling Vata Dosha in all types of Mutraghata. So it can be said that the function of detrusor muscle of bladder might be improved by controlling Apana Vayu with the help of Uttar basti. Dhanyaka (Coriandrum Sativum) has Choriandrol which is diuretic and Gokshur has Diosgenin which have anti proliferative activity against prostate cancer cells and relieve symptoms of BPH i.e. nocturia, increased frequency and prostate enlargement. Hence it is scientifically proven that these drugs played important role in symptomatic relief in cases of BPH. So it can be concluded that the Uttra Basti of DG Ghrita is effective in treatment of BPH definitely.

The cardinal symptoms of prostate like increased frequency, Nocturia, weak stream, incomplete voiding were relieved completely in this patient. The average Urine Flow Rate was increased. The size of Prostate and Post Voidal Residual Urine volume were decreased. So it can be said that the trial drug \& procedure have some effect for treat $\mathrm{BPH}$.

\section{Conflict of interest: None}

\section{References}

1. Das. S. A Concise Textbook of Surgery. 9ed. Kolkata; Dr. S. Das; 2016. 1271p.

2. Kaviraj Ambikadatta Shastri. Sushruta Samhita (Part 2) with Ayurved Tattva Sandeepika commentary. Varanasi; Chaukhambha Sanskrit Sansthan; 2011. 540-44p.

3. Ambikadatta Shastri. Bhajshajya Ratnavali with Hindi commentary. 14th edition. Varanasi; Chaukhambha Sanskrit Sansthan; 2001. 498p.

4. https://www.urospec.com/uro/Forms/ipss.pdf \#1 dated 09-10-2019 time 13:04 IST.

5. Shukla V, Tripathi R. Charaka Samhita with Vaidyamanorama Hindi commentary. Reprint edition. Delhi; Chaukhambha Sanskrit Pratishthan; 2010. 370-71p. 


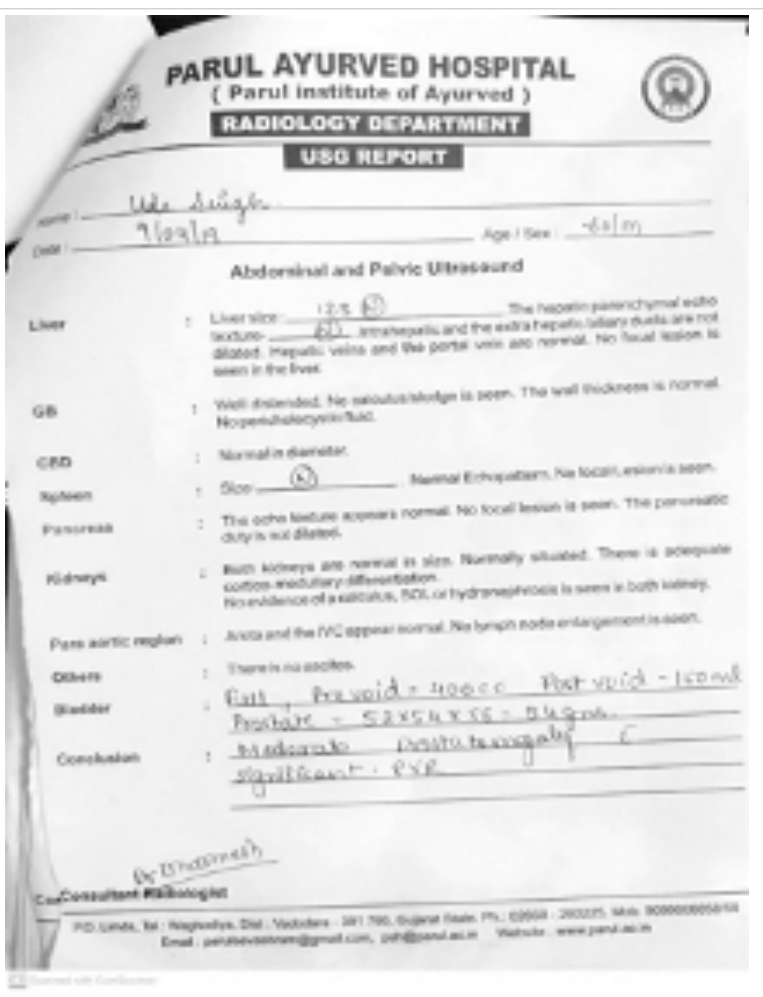

USG Reports Before Treatment

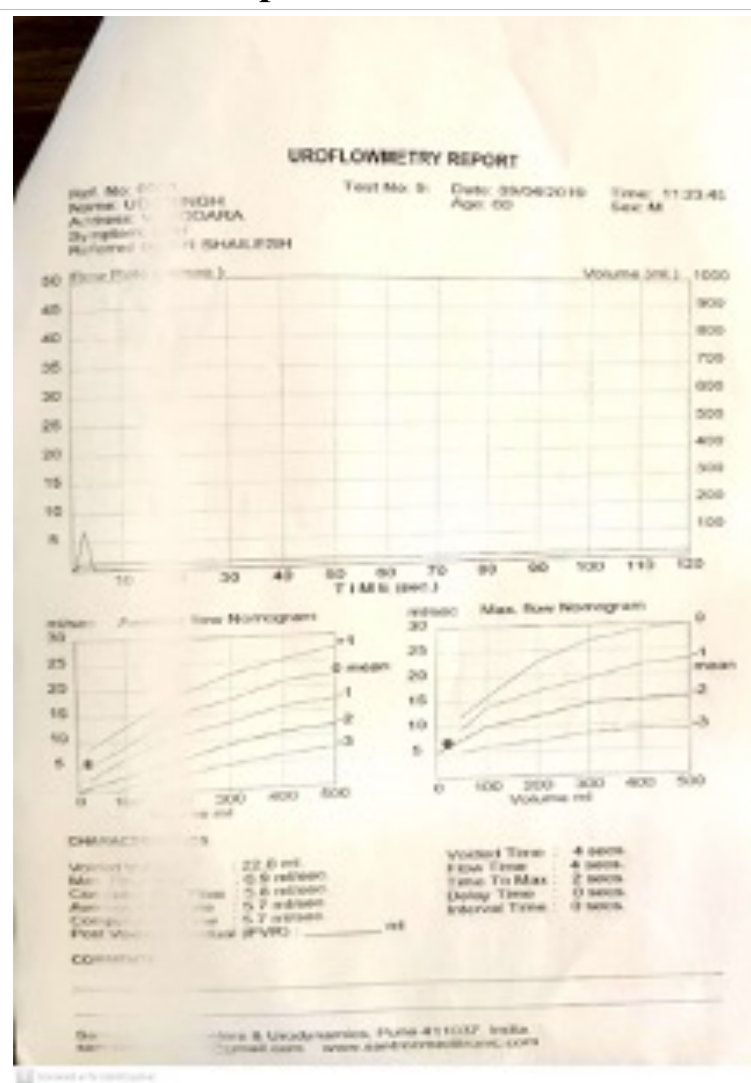

Uroflometry before treat

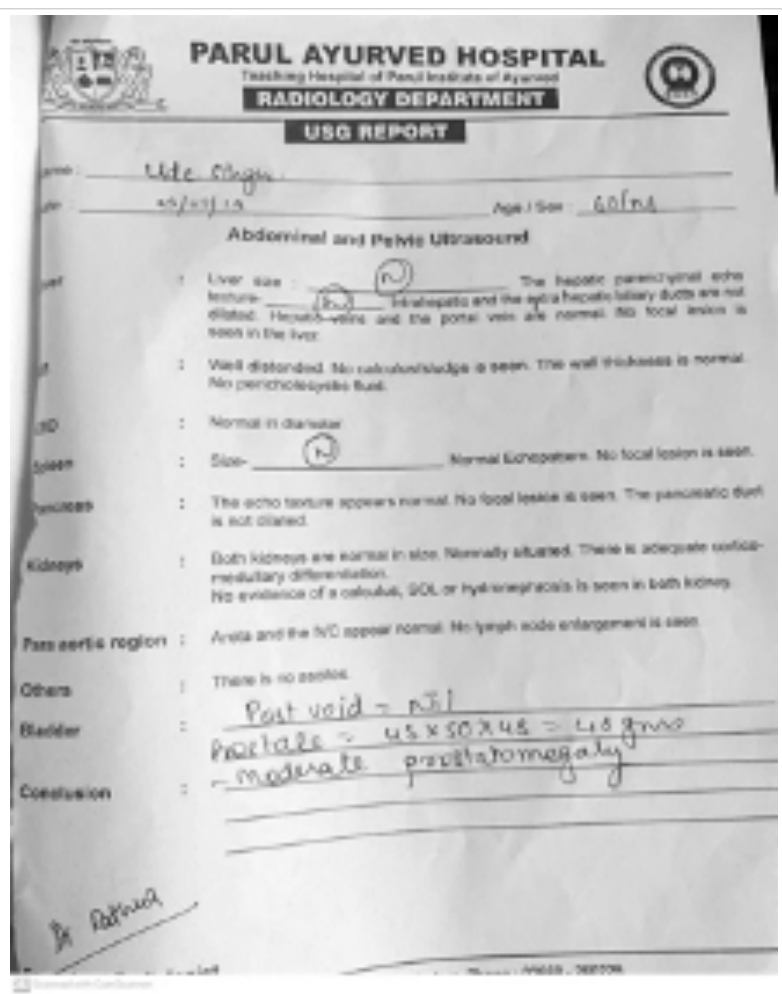

USG Reports After Treatment

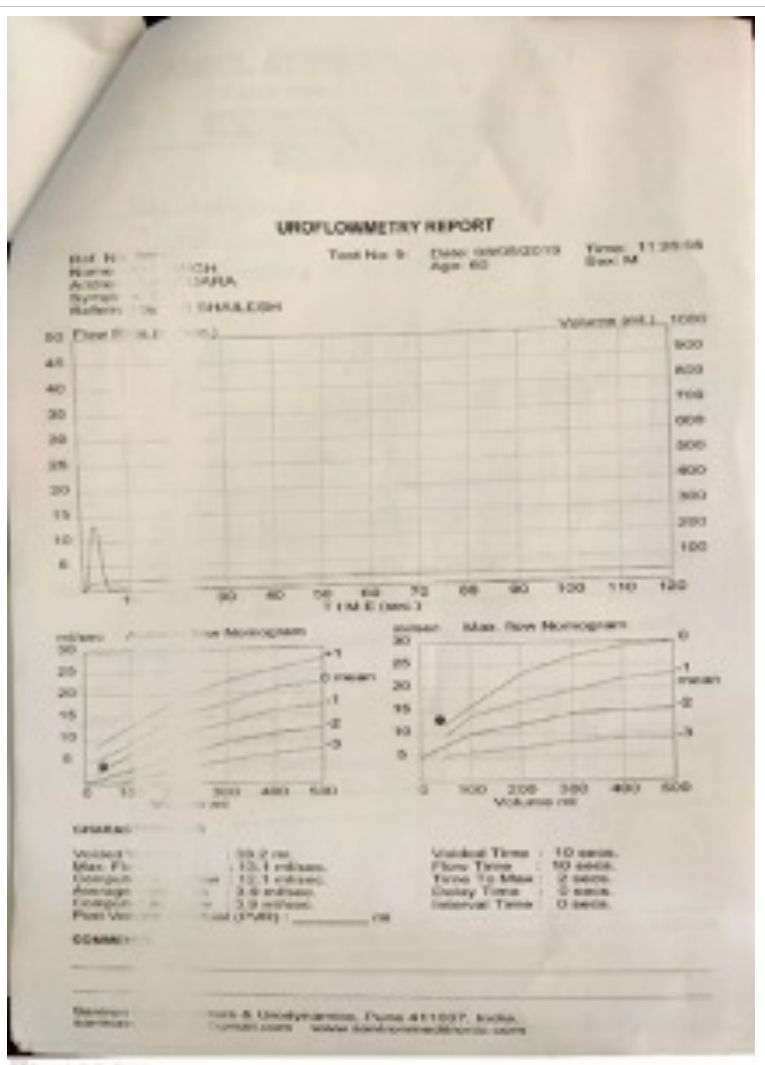

Uroflometry After Treatment 